УДК: 378.091.12:005.336.5]:81'243'272

https://doi.org/10.52058/2786-4952 -2021-4(4)-45-52

Shmelkova Anna Mykolayivna Candidate of Pedagogical Sciences, Associate Professor of the Department of Business Communication, Zaporizhia National University, Zhukovsky St., 55, Zaporizhia, 69600, tel.: (061) 289-41-06, e-mail: shmelanna1205@gmail.com, https://orcid.org/0000-003-2475-3739

Ubeyvolk Oksana Oleksandrivna Candidate of Philosophical Sciences, Associate Professor of the Department of Business Communication, Zaporizhia National University, Zhukovsky St., 55, Zaporizhia, 69600, tel.: (061) 289-41-06, e-mail: Ubvolk@gmail.com, https://orcid.org/0000-0003-4257-8209

\title{
FORMATION OF FOREIGN LANGUAGE COMMUNICATIVE COMPETENCE OF MASTERS AT UNIVERSITIES
}

Abstract. This article is devoted to the formation of foreign language communicative competence of masters. Professional training in foreign languages is now recognized as a priority in the process of updating in the educational system. There is a need to look at the learning process in a new way in general and for learning foreign languages in particular. Foreign language communication becomes an important component in professional activity of specialists. The competence in a foreign language

is defined as an integrative system-value and personal-professional quality based on special foreign language knowledge and skills, values of the future professional communication activity, awareness of its motives and provides the ability of the individual to implementation of foreign language, interlingual, intercultural and interpersonal communication in oral and written forms for various general and professional economic issues. Analysis of pedagogical scientific and methodological sources showed that there is a large number of methodological directions and technologies in teaching foreign languages in non-language universities, the result of which should be not only the acquisition different communication skills in foreign language by students, but also obtaining special knowledge in the specialty. Considering a foreign language as a means of formation professional orientation of the future specialist, it should be noted that during the study professionally oriented language material establishes a two-way connection between the student's efforts to gain special knowledge from their future profession and the success of language acquisition. Professionally oriented learning is a professional orientation not only of the educational content material, but also activities that consist of techniques and operations that form professional skills. At first, it needs the integration of a foreign language with profiling subjects; at second, in front of a foreign language teacher the 
Журнал«Герспективитаінновації науки»

(Серія«Гедагогіка», Серія«Гцихологія», Серія«Медицинв»

№4(4) 2021

task is put to teach the future specialist on the basis of interdisciplinary links to use a foreign language as a means of systematic expansion of their professional knowledge, as well as a tool to help to form professional skills and abilities. Thirdly, it involves the use of forms and methods of teaching, which will help to form the necessary professional skills and abilities of the future specialist. It is defined that the formation of foreign language competence of masters is a comlicated process the aim of which is to activate internal resources and professionally important communicative qualities of students that contribute to the accumulation and enrich the knowledge, skills and abilities necessary for practical use foreign language in future situations of professional communication.

Keywords: a foreign language, professional activity of specialists, communicative competence, professional training in foreign languages.

Шмелькова Ганна Миколаївна кандидат педагогічних наук, доцент кафедри ділової комунікації, Запорізький національний університет, м вул. Жуковського, 55, Запоріжжя, 69600, тел.: (061) 289-41-06, e-mail: shmelanna1205@gmail.com, https://orcid.org/0000-003-2475-3739

Убейволк Оксана Олександрівна кандидат філософських наук, доцент кафедри ділової комунікації, Запорізький національний унівеситет, вул. Жуковського, 55, м. Запоріжжя, 69600, тел.: (061) 289-41-06, e-mail: Ubvolk@gmail.com, https://orcid.org/0000-0003-4257-8209

\section{ФОРМУВАННЯ ІНШОМОВНОЇ КОМУНІКАТИВНОЇ КОМПЕТЕНЦІЇ МАГICTPIB У $3 B O$}

Анотація. Ця стаття присвячена формуванню іншомовної комунікативної компетентності магістрів. На сьогодні професійне навчання іноземним мовам визнано пріоритетом у процесі оновлення системи освіти. Існує потреба поглянути на процес навчання в цілому по-новому і зокрема на вивчення іноземних мов. Іншомовна комунікація стає важливою складовою професійної діяльності фахівців. Компетентність 3 іноземної мови визначається як інтегративна системно-ціннісна та особистісно-професійна якість, що грунтується на спеціальних іноземних знаннях та навичках, цінностях майбутньої професійної комунікаційної діяльності, усвідомленні іï мотивів та забезпечує здатність особистості до реалізації іншомовного, міжмовного, міжкультурного і міжособистісне спілкування в усній і письмовій формах 3 різних загальних i професійних економічних питань. Аналіз педагогічних науково-методичних джерел показав, що існує велика кількість методологічних напрямків і технологій викладання іноземних мов у немовних університетах, результатом яких має бути не лише набуття студентами навичок спілкування іноземною мовою, а й отримання спеціальних знань за фахом. Розглядаючи 
іноземну мову як засіб формування професійної орієнтації майбутнього спеціаліста, слід зазначити, що під час навчання професійно орієнтований мовний матеріал встановлює двосторонній зв'язок між зусиллями студента здобути спеціальні знання з майбутньої професії та успіхом засвоєння мови. Визначено, що формування іншомовної компетенції магістрів $\epsilon$ складним процесом, метою якого $\epsilon$ активізація внутрішніх ресурсів та професійно важливих комунікативних якостей студентів, що сприяють накопиченню та збагаченню знань, умінь і навичок, необхідних для практичного використання іноземної мови. мова в майбутніх ситуаціях професійного спілкування.

Ключові слова: іноземна мова, професійна діяльність фахівців, комунікативна компетентність, професійна підготовка іноземних мов.

Formulation of the problem. In the modern world today, there is a clear need to revise the approaches to the training of qualified specialists at universities. In modern higher school, a foreign language is considered an integral component of professional training of a future specialist of any profile. The purpose of teaching foreign languages in non-language faculties in universities is to achieve a sufficient level for the practical use of foreign language in future professional activities. At faculties where a foreign language is not a major subject, the issue of choosing teaching strategies remains relevant.

The process of learning a foreign language is organized in an intensive mode due to the short duration of mastering language, therefore, in recent years, the issue of the autonomy of students in the study of the subject and their responsibility for the outcome of the study. A modern qualified specialist must be able to study even the language independently, to be able to solve the assigned tasks effectively, and language learning contributes to this notion.

Analysis of recent research and publications. In the second half of the 20th century, in the methodology of teaching a foreign language, in parallel with various approaches, theories and teaching technologies, a new subject area began to form, in which not the personality of the teacher is emphasized and the teaching process, and the learner and the learning process $[2 ; 3 ; 4]$. In the there are focused language learning strategies, which are aimed to improve the quality of education, to find more effective ways and means of developing foreign language communication. They become the subject of vivid discussion, based on different criteria for their selection.

Learning strategies are another approach to considering the role of the learner in language learning. Some teaching methods describe the strategies in the use of which the students themselves are interested in. Researchers have undertaken a number of attempts to establish a uniform terminology and description of such strategies, but have not reached a consensus. Weinstein and Mayer, for example, understood learning strategies as models behaviors and ways of thinking that learners demonstrate in the learning process and that should influence the process information processing $[4,320]$. D. Richards and D. Platt consider a learning strategy as purposeful thinking and 
behavior with the aim of memorizing and understanding a new information in the learning process $[2,231]$. Cohen claims that language learning strategies can be defined as thoughts and actions deliberately chosen by learners to help them learn and use the language in general and in the performance of specific language tasks [1,28]. Anyway, most scientists understand learning strategies as special actions, patterns of behavior, steps and techniques that are used by learners (often on purpose) to improve their language skills. These strategies can make it easier use of the target language. In other words, strategies are learning tools aimed at subject of training. They are essential for the development of communication skills. At the same time, the intensity of the educational process suggests that the emphasis is shifting from learning strategies to learning strategies, in other words, from teaching to learning $[2 ; 6 ; 7]$. Thus, learning strategies play an important role in language learning and imply an active role of learners in managing their own learning. They can be used in connection with or independently techniques that teachers use.

Formulation of article objectives. The main goal of teaching foreign languages in the master's program of the university is the formation of a special level of communicative competence that is necessary for intercultural and professional communication. In the magistracy of a university, the goal of the English language course is the development and deepening of the professionally oriented language competence of undergraduates, since graduates of the magistracy need a foreign language at present, for a deeper development of the specialty and for practical use in professional activities and everyday business and personal communication.

The main results. Today's education is not possible without application innovative educational technologies. Innovative technologies in the educational process are designed to develop cognitive and creative activity of students, to improve the quality of education and the effectiveness of the use of study time, to reduce the number time spent by students on reproductive activity. Many people pay attention to the importance of using innovative technologies in modern education. domestic and foreign scientists, since the use of innovative technologies can significantly diversify content, methods and forms of training. Moreover, innovative technologies provide students with an unlimited amount of information that can be effectively used as independent work $[1 ; 2 ; 3 ; 6 ; 7]$. Special use of innovative technologies in teaching a foreign language seems to be relevant. Undergraduates acquire the skills of writing abstracts, abstracts of articles, prepare scientific reports and presentations in a foreign language, which can be useful in their further scientific activities and when speaking at international scientific conferences.

Since teaching a foreign language in a magistracy is the final stage in teaching this subject at a university, issues related to future professional activities and employment become most relevant. Therefore, in English classes, undergraduates learn to draw up a package of documents (resume, recommendation, cover letter) for hiring, get acquainted with the rules of conduct during an interview and consolidate them in role-playing games. 
Much attention is paid to preparing a speech for self-presentation to employers. When working on vocabulary, the specificity of the lexical means of business (its lexical and phraseological norm, standard language clichés, etc.) and professional (sublanguage of professional communication) languages are also taken into account, which is necessary for reading business correspondence, processing business documents and writing letters in English, as well as for conducting business negotiations and drafting contracts. All this becomes especially important in connection with the expansion of market relations and with the processes of globalization and integration, when undergraduates have to work with Englishlanguage documentation, translate and respond to a large number of letters.

The main purpose of teaching a foreign language in the magistracy of a nonlinguistic university is an achievement by undergraduates the level of practical proficiency in a foreign language, allowing to use it in their future professional activities and scientific work, including everyday and professional communication.

One of the goals of teaching foreign languages for undergraduates is the creation of basic knowledge, skills and abilities to understand correctly, translate texts into foreign language. A specialist with magister degree, should be erudite broadly, own the methodology of scientific creativity, the latest information technologies, various methods of obtaining, processing and fixation of scientific information. He must be able to work with a computer and use all its possibilities for working with information.

The use of modern information technology is today one of the most effective means of increasing success in pedagogical work in the university and the quality of education while learning foreign languages. The need to use new information technologies in educational process in the magistracy is determined as a requirement to the level of training masters, and a continuous increase in the amount of information that is necessary to study and share work during training.

A small number of classroom hours for studying a foreign language to get a new master's degree, increases the importance of independent work in the educational process and makes it especially relevant to create a package of tasks, the execution of which requires the use of personal computer. The main content of independent work, which requires using information technology when teaching a foreign language in a master's degree is to perform a variety of tasks, related to finding information on the Internet. For independent preparation of reports and presentations in a foreign language, undergraduates should be able to use the materials of specialized Web sites, where thematic articles are published and discussions are held on topical issues of modern science. Processing of the received foreign language information is also carried out using the capabilities of personal computer.

One of the traditional types of assignments performed by undergraduates is individual reading of articles in the main speciality. The primary task of this type of educational activity is to teach undergraduates to read texts in the specialty, understand them and literate extraction of professionally relevant information. Individual reading is extensive reading, which involves the ability to read a large amount of text with high 
speed independently, while focusing on the content side of what you read. For individual reading assignments graduate students need to choose the required amount of texts directly in their specialty. These should be scientific articles written by native speakers and published over the past decade.

One of the important components of the textual direction of training is abstracting, annotating and translation (abstract and full-text) a scientific text in the specialty. In the daily practice there is a constant need for an oral or written presentation of an article in the native language and a summary in foreign language, paying attention to the materials that contain valuable information. The practice of publishing scientific articles is also widespread in magazines and thematic collections in the native language with an abstract presentation of their main content in a foreign language. Therefore, one of the tasks of teaching English in a magistracy of a nonlinguistic university is the formation of the skills to work with the original foreignlanguage literature in the specialty and, in particular, the development of skills in abstracting and compiling written reviews. In the process of working on the essay, the master student, improving his knowledge of a foreign language, at the same time comprehends the issues of the studied subject deeper, as he analyzes various points of view, phenomena, facts and events. So, full-text translation may be an assignment for independent work with the text at home. A selective checking of the correctness of understanding of the oral, and sometimes written translation performed at home, gives the teacher understanding of how well the master's student can use the grammar and terminology in his field of studying, how clearly he can present the content of the scientific text. Writing and translating of informative abstracts, as well as similar annotations on professionally oriented materials, is one of the most demanded types of foreign language activities in the field of science and ways of forming practical skills of intercultural communication in a foreign language among undergraduates.

So, translation can be a good helper in teaching a foreign language. No foreign language course can be started without translation. Having received a complex text for "comprehension", the undergraduate seeks, first of all, to translate this text into his native language, since he does not think in a foreign language. Consequently, explicit or implicit translation into the native language is always present at the first stage of training. Instilling the same skills and abilities that contribute to the implementation of this goal is the task of the teacher. Translation is regarded by many authorities as an important and necessary form of study. It is the basis of a consciously comparative approach to teaching foreign language vocabulary and grammar and justifies the dosed use of the native language in the study of a foreign language.

Practice shows that effective work is not only about analysis and translation into native language of the original texts, but also their reverse translation with subsequent analysis of errors, deviations from the Anglo-American sociocultural standards of writing in the field of scientific and business communication style. It is also useful to edit ready-made scientific texts. There are different ways to extend bilateral translation. This is primarily an interview, various conversations and meetings, official 
negotiations, press conferences, dissertation defense in a foreign language etc. Bilateral translation can be used as a reliable remedy teaching various aspects of the language. With help of bilateral translation lexical, phonetic and grammatical skills can be consolidated.

Such assignments allow students to save time, learn the material faster. In addition, students learn to analyze translation and compare used language tools in foreign and Ukrainian languages. These tasks allow to give the teacher to students texts and dialogues of various level of difficulty, regardless of the material covered, which contributes to the diversity of those used in the educational process, which, in turn, not only arouses students' interest in learning the language, but also expands their areas of knowledge.

Conclusion. Although training in translation in a professional level is not the main goal of the course, we consider it as a necessary component of professional training of a master student. There are several reasons to be sure that the perception and understanding of a foreign language text cannot be conceived without translation, which should be considered as the main means of developing understanding. Untranslated understanding, as a rule, can be achieved later in the process of independent work of undergraduates with literature in the specialty.

Communicative competence is considered to be formed if the future specialist uses a foreign language to acquire and expand their professional knowledge independently. Knowledge of a foreign language and its use requires knowledge of socio-cultural features of native speakers, a wide range of verbal and nonverbal communication. The socio-cultural component in the content of foreign language teaching plays an important role in the development of the student's personality, as it allows not only to get acquainted with the cultural heritage of the country whose language is studied, but also to compare it with the cultural values of the country.

\section{References:}

1. Oprjatnij, S.M. (2005). Osnovni naprjami vdoskonalennja profesijnogo navchannja derzhavnih sluzhbovciv dilovoï anglijs'koï movi [The main straightforward in-depth knowledge of the professional education of the state services of the English language]. Universitets'ki naukovi zapiski University of Science Notes, 1-2 (13-14), 312-316 [in Ukrainian].

2. Passov, E.I., Kuzovleva, N.E. (2010). Osnovy kommunikativnoj teorii i tehnologii inojazychnogo obrazovanija [Fundamentals of communication theory and technology of foreign language education]. M. : Russkij jazyk ; Kursy [in Russian].

3. Stepanova, M.M. (2010). Obuchenie delovomu anglijskomu jazyku v magistrature nelingvisticheskogo vuza [Teaching business English in the magistracy of a non-linguistic university]. Proceedings from XXXIX Mezhdunar. filologicheskoj konf. - The XXXIX Int. philological conf. (pp. 51-54). SPb.: OOO «Kul'tinformpress» [in Russian].

4. Sura, N.A. (2003). Metodichne zabezpechennja ta organizacija navchannja kursu profesijno orientovanogo spilkuvannja inozemnoju (anglijs'koju) movoju u VNZ [Methodically securing and organizing the course of a professionally organized exchange of earthly (English) language at VNZ]. Visnik LDPU im. T.G. Shevchenka - Bulletin of the LDPU im. T.G. Shevchenko, 7 (63), 205-207 [in Ukrainian].

5. Sysoev, P.I. (2013). Informacionnye i kommunikacionnye tehnologii v lingvisticheskom obrazovanii [Information and communication technologies in linguistic education]. M. : Librokom [in Russian]. 
6. Teljashenko, V.L. (2003). Profesijno ori€ntovane navchannja studentiv inozemnoï movi v nemovnomu vuzi [Professionally organized students of foreign languages in a non-military university]. Theory and practice of sovereign governance - Theory and practice of sovereign governance, 78-81 [in Ukrainian].

7. Miller, M.D. (2014). Minds online : Teaching effectively with technology. Cambridge, Massachusetts : Harvard University Press.

8. Camilleri, M. A., \& Camilleri, A. C. (2017). Digital learning resources and ubiquitous technologies in education. Technology, Knowledge and Learning, 22(1), 65-82.

\section{תimepamypa:}

1. Опрятний C.M. Основні напрями вдосконалення професійного навчання державних службовців ділової англійської мови // Університетські наукові записки. - 2005. - № 1-2 (1314). - C. 312-316.

2. Пассов Е.И., Кузовлева Н.Е. Основы коммуникативной теории и технологии иноязычного образования : метод. пособие для препод. рус. яз. Как иностр. - М. : Русский язык ; Курсы, 2010. - 568 с.

3. Степанова М.M. Обучение деловому английскому языку в магистратуре нелингвистического вуза // Деловой иностранный язык: Сб. науч. трудов. Вып. 4. Материалы XXXIX Междунар. филологической конф. (18 марта 2010 г.) / отв. ред. Л.А. Девель. - СПб.: ООО «Культинформпресс», 2010. - С. 51-54.

4. Сура Н.А. Методичне забезпечення та організація навчання курсу професійно орієнтованого спілкування іноземною (англійською) мовою у ВНЗ // Вісник ЛДПУ ім. Т.Г. Шевченка. - 2003. - №7 (63). - С. 205-207.

5. Сысоев П.И. Информационные и коммуникационные технологии в лингвистическом образовании : учеб. пособие. - М. : Либроком, 2013. - 264 с.

6. Теляшенко В.Л. Професійно орієнтоване навчання студентів іноземної мови в немовному вузі // Теорія та практика державного управління: [Збірник] / Нац. акад. держ. упр. при Президентові України, Харк. регіон. ін-т [Редкол.: Г.І.Мостовий та ін.]. - Вип.4. Актуальні питання навчання іншомовної комунікації у вищих навчальних закладах: матеріали наук.практ. конф., 20 травня 2003 р. - Х: Магістр, 2003. - С. 78-81.

7. Miller, M.D. (2014). Minds online : Teaching effectively with technology. Cambridge, Massachusetts : Harvard University Press.

8. Camilleri, M. A., \& Camilleri, A. C. (2017). Digital learning resources and ubiquitous technologies in education. Technology, Knowledge and Learning, 22(1), 65-82. 